\title{
PENERAPAN HUKUM MENURUT PERATURAN PEMERINTAH NOMOR 24 TAHUN 2010 TENTANG PENGGUNAAN KAWASAN HUTAN DI PROVINSI RIAU.
}

\author{
Fandi Satria \\ satriafandi966@ymail.com \\ Mahasiswa Magister Kebijakan Publik Universitas Sebelas Maret \\ Lego Karjoko. \\ Email: Lkarjoko@staff.uns.ac.id \\ I Gusti Ayu Ketut Rachmi Handayani \\ Email: ayu_igk@staff.uns.ac.id \\ Dosen Magister Ilmu Hukum Universitas Sebelas Maret Surakarta
}

\begin{abstract}
The purpose of this article is to describe the Application of Laws According to Government Regulation Number Year 2010 concerning the Use of Forest Areas in Riau Province under the management of related technical agencies namely the Riau Provincial Environment and Forestry Agency in the context of the use of efficient forest areas, in particular associated with: The Use of Forest Areas, and the Constraints Factor in the Application of Laws concerning the Use of Forest Areas that occurred at the Riau Plantation Office on unhealthy plantation companies. This study uses a prescriptive normative approach, finding the law in concreto on the Law on Plantation Law in Riau Province. The type of data used is secondary data. Secondary data sources used include primary data, secondary data, and Non-Legal data. Data collection technique used is literature study. Some data then asked for explanation and confirmation from Plantation Office of Riau Province. Data analysis techniques used with the method of syllogism and interpretation by using deductive thinking patterns. Based on the results of research and discussion, the following conclusions are derived: First, the application of the law concerning the use of forest areas in Riau Province has not been in accordance with the provisions contained in Law No. 41 Year 1999, Government Regulation No. 24 of 2010. Second, Factor Constraints in Implementation of Laws According to Government Regulation No. 24 of 2010 on the Use of Forest Areas in Riau Province.among others, law enforcers, infrastructure facilities, communities that are not in accordance with the provisions contained in Law no. 41 of 1999 and Government Regulation No. 24 of 2010 .
\end{abstract}

Keywords:Application of Laws, Use of Forest Areas, Obstacle Factor 


\begin{abstract}
Abstrak
Tujuan artikel ini adalah untuk mendeskripsikan Penerapan Hukum Menurut Peraturan Pemerintah Nomor Tahun 2010 tentang Penggunaan Kawasan Hutan di Provinsi Riau yang berada dibawah pengelolaan dinas teknis terkait yaitu Dinas Lingkungan Hidup dan Kehutanan Provinsi Riau dalam rangka penggunaan Kawasan hutan yang berdaya guna, khususnya dikaitkan dengan: Peraturan Penggunaan Kawasan Hutan, dan Faktor Kendala Dalam Penerapan Hukum Tentang Penggunaan Kawasan Hutan yang terjadi di Dinas Perkebunan Provinsi Riau terhadap perusahaan perkebunan yang tidak sehat.Penelitian ini menggunakan pendekatan normatif bersifat preskriptif, menemukan hukum in concreto mengenai Peraturan Perundang-undangan Perkebunan di Provinsi Riau.Jenis data yang digunakan yaitu data sekunder.Sumber data sekunder yang digunakan mencakup data primer, data sekunder, dan data Non Hukum.Teknik pengumpulan data yang digunakan yaitu studi kepustakaan.Beberapa data kemudian dimintakan penjelasan dan konfirmasi dari Dinas Perkebunan Provinsi Riau.Teknik analisis data yang digunakan dengan metode silogisme dan interpretasi dengan menggunakan pola berpikir deduktif.Berdasarkan hasil penelitian dan pembahasan dihasilkan simpulan sebagai berikut: Kesatu,Penerapan Hukum Tentang Penggunaan Kawasan Hutan di Provinsi Riau Belumlah sesuai dengan ketentuan yang terdapat dalam UU No. 41 Tahun 1999, Peraturan Pemerintah Nomor 24 Tahun 2010. Kedua,Faktor Kendala Dalam Penerapan Hukum Menurut Peraturan Pemerintah Nomor 24 Tahun 2010 Tentang Penggunaan Kawasan Hutan Di Provinsi Riau.anatara lain, penegak hukum, sarana prasarana, masyarakat yang belum sesuai dengan ketentuan yang terdapat dalam UU No. 41 Tahun 1999 dan Peraturan Pemerintah Nomor 24 Tahun 2010.
\end{abstract}

Kata Kunci:Penerapan Hukum, Penggunaan Kawasan Hutan. Faktor Penghambat.

\title{
A. Pendahuluan.
}

Hutan sebagai karunia Tuhan Yang Maha Esa yang merupakan kekayaan alam yang tak ternilai harganya dan wajib disyukuri.Anugerah bangsa Indonesia ini merupakan amanah yang patut dijaga kelestariannya karena fungsi hutan bagi hidup dan kehidupan manusia, flora, dan fauna sangat vital.Fungsi tersebut, diantaranya manfaat secara nyata, baik manfaat ekologi, sosial budaya, maupun ekonomi.

Dalam kedudukannya sebagai salah satu penentu sistem penyangga kehidupan, hutan telah memberikan manfaat yang besar bagi umat manusia, oleh karena itu harus dijaga kelestariannya.Hutan mempunyai peranan sebagai penyerasi dan penyeimbang lingkungan global, sehingga keterkaitannya dengan 
dunia internasional menjadi sangat penting, dengan tetap mengutamakan kepentingan nasional. (Penjelasan UURI Nomor 41 Tahun 1999 Tentang Kehutanan)

Kelestarian dimaksud adalah manfaat yang dapat dinikmati tidak hanya pada generasi sekarang, namun generasi yang akan datang dapat pula menikmati keberadaan hutan. Hal ini sejalan dengan amanat Pasal 3 huruf e Undang-Undang Nomor 41 Tahun 1999 tentang Kehutanan yang mengatur bahwa penyelenggaraan kehutanan bertujuan untuk sebesar-besarnya kemakmuran rakyat yang berkeadilan dan berkelanjutan dengan menjamin distribusi manfaat yang berkeadilan dan berkelanjutan. Pengaturan tentang kehutanan diatur melalui Undang-Undang Negara Republik Indonesia Nomor 5 Tahun 1967 tentang Ketentuan-ketentuan Pokok Kehutanan (Lembaran Negara Republik Indonesia Tahun 1967 Nomor 8, Tambahan Lembaran Negara Nomor 2823) yang telah diperbaharui dengan Undang-Undang Negara Republik Indonesia Nomor 41 Tahun 1999 tentang Kehutanan (Lembaran Negara Republik Indonesia Tahun 1999 Nomor 167, Tambahan Lembaran Negara Nomor 3888). Sedangkan pengaturan kawasan konservasi ditetapkan melalui Undang-Undang Negara Republik Indonesia Nomor 5 Tahun 1990 tentang Konservasi Sumber Daya Alam dan Ekosistemnya (Lembaran Negara Republik Indonesia Tahun 1990 Nomor 49, Tambahan Lembaran Negara Nomor 3419).

Sesuai dengan amanat Undang-Undang Dasar Tahun 1945 Pasal 33 ayat (3) (Undang-Undang Dasar Tahun 1945 Pasal 33 ayat (3)) yaitu bumi, tanah, air dan kekayaan yang terkandung di dalamnya dikuasai oleh negara dan dipergunakan untuk sebesar-besarnya kemakmuran rakyat. Wewenang pemerintah di bidang kehutanan sesuai dengan Pasal 4 UndangUndang Nomor 41 Tahun 1999 tentang Kehutanan adalah mengatur, mengurus hal yang berkaitan dengan hutan, kawasan hutan dan hasil hutan, menetapkan atau mengubah status kawasan hutan, mengatur dan menetapkan hubungan hukum serta mengatur perbuatan hukum mengenai kehutanan. Hutan adalah suatu kesatuan ekosistem berupa hamparan, sumber daya alam hayati, didominasi pepohonan dalam persekutuan alam lingkungannya, yang satu dengan lainnya tidak dapat dipisahkan.Kawasan hutan 
adalah wilayah tertentu yang ditunjuk dan atau ditetapkan oleh pemerintah dipertahankan keberadaannya sebagai hutan tetap.

Dalam UU No. 41 tahun 1999,penatagunaan kawasan hutan adalah kegiatanpenetapan fungsi dan penggunaan kawasanhutan. Berdasarkan fungsi pokoknya, kawasanhutan di bagi menjadi: (1) Hutan konservasi,(adalah kawasan hutan dengan ciri khastertentu, yang mempunyai fungsi pokoksebagai kawasan pengawetan keanekaragamantumbuhan dan satwa serta ekosistemnya, yangjuga berfungsi sebagai wilayah sistempenyangga kehidupan, terdiri dari kawasanhutan suaka alam, kawasan hutan pelestarianalam, dan taman buru); (2) Hutan lindung(adalah kawasan hutan yang mempunyaifungsi pokok sebagai perlindungan system penyangga kehidupan untuk mengatur tata air,mencegah banjir, mengendalikan erosi,mencegah intrusi air laut, dan memeliharakesuburan tanah) dan (3) Hutan produksi(adalah kawasan hutan yang mempunyaifungsi pokok memproduksi hasil hutan berupabenda-benda hayati, non hayati dan turunannya, serta jasa yang berasal dari hutan).(Epi Syahadat,Jurnal Analisis Kebijakan Kehutanan Vol. 9 No. 2, Agustus 2012: 131 - 143)

Walaupun pengaturan tentang kehutanan di Indonesia telah dipayungi dengan berbagai Undang-undang, namun kondisi penegakan hukum di bidang kehutanan pada saat ini belum sesuai dengan yang diharapkan.Permasalahan di bidang kehutanan cenderung makin menumpuk dan mengarah jadi sumber ancaman ketentraman, bahkan pada saat ini telah mengalami perkembangan yang cukup mengkhawatirkan.

Keberhasilan pembangunan sektor kehutanan dalam menunjang pertumbuhan ekonomi nasional selama ini dicapai melalui berbagai kegiatan kehutanan yang bertumpu pada eksploitasi hasil hutan kayu dan kegiatan pertambangan dengan tujuan utama untuk peningkatan devisa negara. Peranan kehutanan sebagai penggerak ekonomi nasional yaitu dalam penyediaan hutan dan lahan sebagai modal awal untuk pembangunan berbagai sektor, terutama perkebunan dan industri lain. Kemudian semakin bervariasi membiayai usaha perbankan, real 
estate, dan berbagai kegiatan ekonomi lainnya, yang merupakan penggerak ekonomi potensial, amat kompleks dan saling terkait.

Seiring dengan perkembangan kehidupan masyarakat modern dalam menghadapi globalisasi serta adanya proses industrialisasi dan modernisasi akan menumbuhkan perubahan proses sosial dalam tata kehidupan masyarakat. Proses industrialisasi dan modernisasi dan terutama industrialisasi kehutanan telah berdampak besar pada kelangsungan hutan sebagai penyangga hidup dan kehidupan mahluk di dunia. Hutan merupakan sumber daya yang sangat penting tidak hanya sebagai sumber daya kayu, tetapi lebih sebagai salah satu komponen lingkungan hidup. (Siswarno Sunarso,2005:6)

Kehutanan adalah sebuah fenomena. Sektor publik yang berbasis pengelolaan dan pemanfaatan sumber daya alam itu sejak awal diyakini oleh semua pihak sebagai sektor yang berkelanjutan (sustain). (Winarno Budyatmojo,2008:2)Selama ini arus pemikiran yang berkembang terhadap penguasaan hutan oleh negara menempatkan negara selaku pihak yang mengelola hutan dengan tujuan yang berorientasi kepada ekonomi terutama untuk diambil kayunya.

Perubahan paradigma pemerintah dalam kegiatan kehutanan pada era orde baru dari yang semula hanya berbasis ekonomi kemudian berubah menjadi tiga yaitu tidak hanya berbasis ekonomi tetapi juga memperhatikan aspek ekologi dan sosial.Perubahan ini telah membawa pengaruh terhadap perubahan pengelolaan hutan secara keseluruhan yaitu dengan berubahnya perangkat kebijakan yang mengatur perencanaan pengelolaan hutan, baik berupa undangundang kehutanan, peraturan-peraturan pemerintah dan peraturan-peraturan kehutanan lainnya.

Permasalahan kawasan hutan tidak pernah selesai dibicarakan, dan isu tersebut semakin memanas, karena penyelesaiannya belum optimal.Kerusakan lingkungan yang ditimbulkannya, kemudian menyebabkan bencana alam dan bencana ekonomi yang berkesinambungan.Hal tersebut merupakan konsekuensi logis dari fungsi hutan yang pada hakikatnya adalah sebuah ekosistem yang di dalamnya 
mengandung tiga fungsi dasar yaitu fungsi produksi, fungsi lingkungan dan fungsi sosial (Nurdjana, Teguh Prasetyo,2005:4).

Mahfud MD juga mengatakan bahwa hukum merupakan produk politik, sehingga karakter produk hukum sangat ditentukan oleh perimbangan kekuatan politik (konfigurasi politik) yang melahirkan(Nurdjana, Teguh Prasetyo,2005:293).Demikian juga perkembangan hukum di Indonesia, terutama yang menyangkut perkembangan kehutanan mengikuti arah politik yang ada pada waktu itu.Apa sesungguhnya yang menjadi keinginan dan tujuan para pemegang kekuasaan, baik kekuasaan pemerintah maupun kekuasaan pejabat politik, maka penerapan hukum kehutanan itu diarahkan kepada kebijakan tersebut.

Dalam beberapa tahun terakhir ini, banyak terjadi kawasan hutan yang dibuka untuk kegiatan perkebunan kelapa sawit yang belum mendapat izin pelepasan kawasan hutan dan tambang yang belum mendapat izin pinjam pakai kawasan hutan dari Menteri Kehutanan.Di samping itu lahan-lahan sisa penebangan di bekas-bekas Hak Pengusahaan Hutan (HPH) yang tidak produktif lagi dengan luasan yang sangat besar tersebut sangat cocok dipakai untuk kegiatan non kehutanan.

Kepatuhan terhadap hukum bukan merupakan persoalan baru dalam hukum dan ilmu hukum.Kepatuhan hukum bukan merupakan fungsi dari peraturan hukum semata, melainkan juga dari mereka yang menjadi sasaran pengaturan hukum tersebut (Satjipto Rahardjo, 2010:209).Dalam hal kepatuhan, peraturan tidak dapat dilihat sebagai satu-satunya faktor, melainkan juga ditentukan oleh bagaimana sikap masyarakat menanggapi hukum yang ditujukan kepadanya itu.Ketidakpatuhan itu dilakukan badan usaha dalam penggunaan kawasan hutan tanpa izin.Pembuatan kebun kelapa sawit dan pertambangan, maksud dan tujuannya jelas untuk menaikkan pendapatan masyarakat sekitar hutan dan pendapatan asli daerah.Jadi izin-izin selain kelapa sawit untuk penambangan di dalam kawasan hutan juga dikeluarkan oleh Kepala Daerah (Gubernur/Bupati/Walikota) dimana kebun kelapa sawit atau tambang dibuka. 
Penggunaan kawasan hutan harus disandarkan pada prinsip keadilan dan kesinambungan dengan tetap memperhatikan aspek sosial, lingkungan, dan ekonomi sebagaimana amanat Undang-Undang Nomor 41 Tahun 1999. Jadi segala tindakan yang berpotensi untuk mengurangi bahkan menghilangkan manfaat dari penguasaan dan pengusahaan kawasan hutan pada generasi sekarang dan akan datang tidak boleh dilakukan. Tindakan tersebut diantaranya pengerjaan dan atau pendudukan kawasan hutan secara tidak sah, perambahan kawasan hutan, pembakaran hutan, menebang pohon atau memanen hasil hutan tanpa izin, menambang kawasan hutan tanpa izin, dan pemberian izin pemanfaatan tanpa memperhatikan aspek kemanfataan jangka panjang.

Proses Deforestasi dan degradasi hutan alam di Propinsi Riau berlangsung sangat cepat. Selama kurun waktu 24 tahun (1982-2005) Propinsi Riau sudah kehilangan tutupan hutan alam seluas 3,7 Juta hectare. Pada tahun 1982 tutupan hutan alam di Provinsi Riau masih meliputi 78\% (6.415.655 hektar) dari luas daratan Propinsi Riau 8.225.199 Ha (8.265.556,15 hektar setelah dimekarkan). Hingga tahun 2005 hutan alam yang tersisa hanya 2,743,198 ha (33\% dari luasan daratan Riau). Dalam Kurun waktu tersebut provinsi Riau rata-rata setiap tahun kehilangan hutan alam-nya seluas 160.000 Hectare/tahun dan selama periode 2004 - 2005 hutan alam yang hilang mencapai 200 ribu hectare. Provinsi Riau merupakan wilayah yang memiliki lahan gambut yang terluas di Sumatera 4,044 juta hectare 1 (56,1\% dari luas lahan gambut Sumatera atau $45 \%$ dari luas daratan provinsi Riau).

Permasalahan ini mengingat bahwa ditemui fakta pengerjaaan/penggunaan dan/atau pendudukan kawasan hutan yang dilakukan oleh badan usaha berdasarkan izin yang diberikan oleh gubenur/bupati/walikota sesuai dengan rencana tata ruang wilayah provinsi (RTRWP) bersangkutan.Kawasan hutan yang dimaksud oleh Kementerian kehutanan dalam RTRWP bukanlah merupakan kawasan hutan, sehingga oleh kepala daerah dapat diberikan izin sesuai dengan permohonan, misal untuk perkebunan, pertambangan, dan pemukiman. Dengan demikian, telah terjadi tumpang tindih antara peta kehutanan tentang kawasan 
hutan dan RTRWP yang diatur dalam UndangUndang Nomor 24 Tahun 2002 sebagaimana telah diubah dengan UndangUndang Nomor 26 Tahun 2007 tentang Penataan Ruang.

Berdasakan latar belakang tersebut di atas, maka penulis tertarik untuk menganalisis: Penerapan Hukum Menurut Peraturan Pemerintah Nomor 24 Tahun 2010 Tentang Penggunaan Kawasan Hutan di Provinsi Riau.

\section{B. Metode penelitian.}

Metode penelitian yang dilakukan adalah eksplanasi dengan pendekatan penelitian kualitatif, yaitu menjelaskan dan menggali lebih dalam tentang subjek dan objek, baik seseorang, lembaga, masyarakat dan lain sebagainya serta didasarkan atas hasil studi perpustakaan dan wawancara yang dilakukan serta memberikan analisa terhadap apa yang ditemukan di lapangan dan dihubungkan dengan konsep teori yang relevan. Analisis data yang digunakan adalah analisa yang bersifat penalaran mengenai fenomena-fenomena yang akan diteliti. Setelah data dikumpulkan melalui teknik pengumpulan data, kemudian peneliti menganalisa data secara eksplanasi analisis.Dalam penelitian ini digunakan prinsip analisa kualitatif, dimana metode ini menunjukkan pada prosedur riset yang menghasilkan kualitatif yaitu ungkapan atau catatan orang itu sendiri atau tingkah laku mereka yang terobservasi. Untuk keabsahan data, validitas, realitas serta reliabilitas data, digunakan metode triangulasi yaitu setelah seluruh data terkumpul dari setiap subjek penelitian, kemudian di check, recheck, and cross checkterhadap hasil informasi atau tanggapan yang di berikan oleh subjek penelitian.

\section{Hasil Penelitian dan Pembahasan.}

\section{Penerapan Hukum Menurut Peraturan Pemerintah Nomor 24 Tahun 2010 Tentang Penggunaan Kawasan Hutan di Provinsi Riau.}

Hutan merupakan barang publik, yaitu barang yang tidak punya tandingan (Non Rivalry)dalam konsumsi dan/atau manfaatnya tidak bisa dipisahkan (Non 
Excludable).Hutan bisa memberikan eksternalitas positif maupun negatif, sehingga menimbulkan interdependensi atau ketergantungan atar kabupaten di bagian hulu dan kabupaten di bagian hilir.Sumber daya hutan di Indonesia memiliki kandungan potensi yang sangat besar untuk dikembangkan sebagai sumber pendanaan pembangunan.Potensi yang sangat besar tersebut, dilandasi suatu fakta bahwa Indonesia dikenal sebagai sebuah negara yang memiliki hutan tropis dataran rendah terluas ketiga di dunia, setelah Zaire dan Brasil.Hutan di Indonesia memiliki ekosistem yang beragam mulai dari hutan tropis dataran rendah dan dataran tinggi sampai dengan hutan rawa gambut, rawa air tawar, dan hutan bakau (mangrove), selain itu negara Indonesia merupakan 10 (sepuluh) negara pemilik hutan terluas di dunia.

Kegiatan perlindungan hutan dan kawasan hutan merupakan suatu kegiatan yang sangat penting dan utama karena fakta menunjukkan bahwa kerusakan hutan di Indonesia telah masuk pada skala yang sangat mengkhawatirkan dan oleh karena itu sangat pantas apabila pemerintah menaruh perhatian pada penggunaan kawasan hutan.

Penggunaan kawasan hutan diatur dalam UU No 41 Tahun 1999 tentang Kehutanan dan PP No. 24 Tahun 2010 tentang Penggunaan kawasan Hutan. Kegiatan perlindungan hutan merupakan bagian yang tidak terpisahkan dari pengelolaan hutan. Hal ini pada Pasal 2 PP No. 45 Tahun 2004 dinyatakan bahwa perlindungan hutan merupakan bagian dari kegiatan pengelolaan hutan. Kegiatan perlindungan hutan sebagaimana dimaksud pada ayat (1) dilaksanakan pada wilayah hutan dalam bentuk unit atau kesatuan Pengelolaan Hutan Produksi (KPHP) (I Gusti Ayu Ketut Rachmi Handayani,Jurnal EKOSAINS I Vol. IV I No. 2 | 11 Desember 2016).

Usaha perlindungan hutan adalah suatu usaha untuk mencegah terjadinya kerusakan hutan "akibat pendudukan hutan secara tidak sah, penggunaan hutan yang menyimpang dari fungsinya, dan pengusahaan hutan yang tidak bertanggungjawab, penambangan liar, pencurian kayu dan penebangan tanpa izin, penggembalaan ternak dan akibat kebakaran, gangguan hama, dan penyakit serta 
daya alam" (Panji Suminar,2004:268). Kerusakan hutan itu sendiri disebabkan oleh faktor-faktor pertumbuhan penduduk yang sangat pesat, penyempitan luas tanah pertanian, disertai keadaan sosial ekonomi masyarakat di sekitar hutan, perladangan berpindah-pindah, sempitnya lapangan pekerjaan, dan kurangnya kesadaran masyarakat akan arti pentingnya fungsi hutan dan lain-lain (H.S. Salim, 2005:114).

Penegakan hukum lingkungan di sektor kehutanan memegang peran penting, baik untuk kegiatan sektor kehuatan sendiri maupun dalam upaya pelestarian fungsi sumber daya alam (SDA) dan lingkungan hidup sebagai tujuan utama PPLH.Hutan sebagai SDA, memiliki fungsi ekonomi, sosial, budaya danekologis yang amat penting bagi kehidupan manusia dan makhluk lainnya yang tidak dapat digantikan oleh sumber daya lainnya.Kerusakan dan terganggunya fungsi-fungsi hutan secara langsung berpengaruh terhadap sistem kehidupan, baik ekosistem maupun sosiosistem yang pada gilirannya mengancam kehidupan umat manusia. Oleh karena itu, tidak ada pilihan lain (A. M. Yunus Wahid,Jurnal Hasanuddin Law Review Vol. 1 No. 1, April (2015)).

Moeljatno memberikan aspek mengenai definisi hukum pidana tersebut bahwa pidana meliputi aspek-aspek, yaitu:

a) Perbuatan-perbuatan yang dilarang oleh pembuat undang-undang yang disertai dengan sanksi bagi siapa yang melanggarnya.

b) Menentukan kapan suatu perbuatan yang dilanggar merupakan suatu tindak pidana sebagaimana telah diatur dalam undang-undang.

c) Bentuk dan penerapan sanksi pidana sesuai dengan perbuatan yang dilanggar dan telah diatur dalam undang-undang.

Sedangkan Simons mengatakan, bahwa hukum pidana material memuat ketentuan-ketentuan dan rumusan-rumusan dari tindak-tindak pidana, peraturanperaturan mengenai syarat-syarat bilamana seseorang itu dapat dihukum, siapa yang dapat dihukum dan bilamana hukuman tersebut dapat dijatuhkan. Pada umumnya orang melakukan suatu tindak pidana itu hanya dapat dihukum, jikalau tindak pidana itu telah seluruhnya diselesaikan, artinya semua unsur-unsur dari 
tindak pidana itu telah terwujud (Winarno Budyatmojo, 2009:1).Namun demikian dalam praktik penyelenggaraan Pemerintah khususnya disektor kehutanan masih dirasa adanya tuntutan rasa keadilan di masyarakat bahwa kebijakan kehutanan belum berpihak kepada rakyat.

Beberapa permasalahan dalam pengelolaan hutan selain tersebut diatas, terdapat masalah antara lainillegal logging yang semakin marak. Berdasarkan data di Departemen Kehutanan diperoleh angka penebangan liar mencapai 50,7 juta m3 per tahun dengan kerugian finansial sebesar Rp 30 trilyun per tahun. Selain hal tersebut masalah penyelundupan kayu (Illegal Trade).Menurut data di Departemen Kehutanan, kayu yang diselundupkan dari pusat-pusat produksi kayu balok dengan tujuan Malaysia, Cina, India dan Vietnam mencapai 10 juta m3 per tahun, dari Papua di selundupkan sebanyak $600.000 \mathrm{~m} 3$ per tahun, selain penyelundupan kayu, perambahan hutan juga perdagangan satwa liar yang dilindungi.

Masalah kebakaran hutan (Forest Fire) juga merupakan masalah dalam pengelolaan hutan sejak tahun 1997 - 1998 telah merusak 9,75 juta hektar kawasan hutan dan hal ini terjadi setiap tahun. Di tahun 2006 ini bahkan terjadi kebakaran di Taman Nasional Tesonilo yang terletak di Provinsi Riau.Taman Nasional ini merupakan tempat habitat gajah Sumatera yang saat ini tempat hidupnya makin sempit akibat kebijakan pembangunan yang sangat bermuatan antroposentris. Permasalahan lain yang terkait dengan masalah pengelolaan hutan adalah hak ulayat atas hutan menjadi hal yang perlu ditangani secara serius. Terkait dengan masalah hak-hak masyarakat hukum adat atas hutan.Selain dari pada itu permasalahan yang sangat menonjol saat ini dalam pengelolaan kawasan hutan adalah adanya tumpang tindih kegiatan pengelolaan hutan dengan kegiatan pertambangan di kawasan hutan.

Disamping itu terdapat pula sebagian areal yang merupakan zona prospek mineral tumpang tindih dengan kawasan hutan lindung atau kawasan hutan konservasi. Dengan lahirnya undang-undang No. 5 Tahun 1990 dan Undangundang No. 41 Tahun 1999 tentang Kehutanan, aktifitas yang berkaitan dengan 
pertambangan umum dan migas menghadapi beberapa kendala baik bagi investor yang telah melaksanakan operasinya maupun bagi calon investor yang akan bermaksud mencari deposit mineral di Indonesia.

Dalam penerapan penggunaan kawasan hutan yang ada diprovinsi riau belumlah menunjukan tanda-tanda keberhasilan atau berjalannya suatu aturan yang lebih baik, ini dapat kita lihat diatas banyaknya persoalan-persoalan yang belum dapat diselesaikan oleh pemerintah pusat maupun pemerintah daerah karena minimnya penegakan hukum yang ada di pusat maupun yang di daerah, sarana perasana, politik kekuasaan, badan hukum tidak merasa tau tentang penggunaan kawasan hutan, dan masyarakat acuh taka acuh dalam persoalan kawasan hutan.

\section{Faktor Kendala Dalam Penerapan Hukum Menurut Peraturan Pemerintah Nomor 24 Tahun 2010 Tentang Penggunaan Kawasan Hutan Di Provinsi Riau.}

Masyarakat dan ketertibannya merupakan dua hal yang berhubungan secara erat, bahkan bisa juga dikatakan sebagai dua sisi mata uang.Susah untuk mengatakan adanya masyarakat tanpa ada suatu ketertiban, bagaimanapun kualitasnya.Ketertiban dalam masyarakat diciptakan secara bersama-sama oleh berbagai lembaga secara bersama-sama seperti hukum dan tradisi. Oleh karena itu dalam masyarakat juga dijumpai berbagai macam norma yang masing-masing memberikan sahamnya dalam menciptakan ketertiban itu. Kehidupan dalam masyarakat yang sedikit banyak berjalan dengan tertib dan teratur ini didukung oleh adanya suatu tatanan, karena adanya tatanan inilah kehidupan menjadi tertib, namun hukum bukanlah satu-satunya lembaga yang menciptakan ketertiban dalam masyarakat.

Hukum kehutanan diperlukan sebagai alat pergaulan sosial dalam masalah kehutanan.Perangkat hukum dibutuhkan dalam rangka menjaga supaya hutan dan sumber daya alam lainnya dimanfaatkan sesuai dengan daya dukung atau kondisi kemampuan hutan itu sendiri.Dalam hukum kehutanan diatur tentang obyek dan 
subyek, yang masing-masing adalah hutan dan manusia. Hutan sebagai obyek pengaturan dilindungi dari perbutan manusia supaya interaksi keduanya tetap berada dalam suasana

Menurut Soerjono Soekanto, masalah pokok penegakan hukum sebenarnya terletak pada faktor-faktor yang mungkin mempengaruhinya. Faktor-faktor tersebut mempunyai arti yang netral, sehingga dampak positif atau negatifnya terletak pada isi faktor-faktor tersebut. Faktor-faktor tersebut adalah sebagai berikut: (Soerjono Soekanto, 2002:15.).

a. Faktor hukumnya sendiri (Undang-Undang);

b. Faktor penegak hukum, yakni pihak-pihak yang membentuk maupun menerapkan hukum;

c. Faktor sarana atau fasilitas yang mendukung penegakan hukum;

d. Faktor masyarakat, yakni lingkungan dimana hukum tersebut berlaku atau diterapkan; dan

e. Faktor Kebudayaan, yakni sebagai hasil karya, cipta, dan rasa yang didasarkan pada karsa manusia didalam pergaulan hidup.

Kelima faktor tersebut saling berkaitan dengan eratnya, oleh karena merupakan esensi dari penegakan hukum, juga merupakan tolok ukur dari efektivitas penegakan hukum. Dengan demikian, maka kelima faktor tersebut akan dibahas disini. Pola-pola penegakan hukum dapat dibedakan dalam bentuk modern dan sederhana.Pada hukum modern, memiliki ciri-ciri formal rasional karena didukung oleh mesin administrasi yang semakin rasional, sedangkan penegakan hukum sederhana masih berada di bawah dominasi yang tradisional atau kharismatik (Siswanto Sunarso, 2005:190).

Oleh karena itu, penulis menggunakan teori hukum dalam menganalisa masalah penggunaan kawasan yang tidak prosedural, melihat dari faktor hukumnya sendiri, faktor pelaksana dan penegak hukum, faktor sarana dan fasilitas, dan faktor mastarakat dan budaya hukum. 


\section{Faktor Hukum.}

Ketentuan penggunaan kawasan hutan yang tidak prosedural terhadap masalah substansi hukum yang diatur dalam Undang-Undang Kehutanan sudah dapat dikatakan baik karena telah mengatur adanya sanksi terhadap yang melakukan pelanggaran.Undang-Undang diartikan dengan peraturan tertulis yang berlaku umum dan dibuat oleh Penguasa Pusat maupun Daerah yang sah. Peraturan atau norma merupakan dasar bagi proses penerapan hukum, berhasil atau tidaknya proses penegakan hukum (efektifitasnya) tergantung pada apakah peraturan yang ada mengenai bidang-bidang kehidupan tertentuk cukup sistematis, apakah peraturan-peraturan yang ada mengenai bidang-bidang kehidupan tertentu secara hierarkis maupun horizontal tidak ada pertentangan-pertentangan, apakah secara kuantitatif dan kualitatif peraturan-peraturan yang mengatur bidangbidang kehidupan tertentu sudah cukup, apakah peraturan yang ada menimbulkan penafsiran ganda, sistimatis penerbitanya sudah sesuai dengan persyaratan yuridis (Hartiwiningsih,2008:63).

\section{Faktor Penegak Hukum.}

Ruang lingkup dari istilah "penegak hukum" adalah luas sekali, oleh karena mencakup mereka yang secara langsung dan secara tidak langsung berkecimpung di bidang penegakan hukum yang tidak hanya mencakup law enforcement, akan tetapi juga peace maintenance, yaitu yang bertugas di bidang kehakiman, kejaksaan, kepolisian, kepengacaraan, dan pemasyarakatan. Petugas yang menegakan atau aparat penegak hukum yang menerapkan peraturan perundangundangan merupakan salah satu faktor pendukunng utama keberhasilan penegakan hukum. Bagaimanapun baiknya suatu peraturan perundang-undangan, bila tidak didukung dengan aparat penegak hukum yang baik dan handal maka jangan diharapkan bahwa suatu penegakan hukum akan berhasil, atau dengan kata lain walaupun suatu peraturan perundangan banyak kelemahannya, apabila didukung dengan aparat penegak hukum yang baik, mempunyai moral, maka penegakan hukum akan berhasil. Keduanya memang saling mendukung, pengaruh mempengaruhi, tetapi persoalan sebenarnya sangat tergantung pada sumber daya 
amanusia, seperti yang pernah dikemukakan oleh Hermann Mennhein, “ It Is Not The Formula That Decides The Issue But The Men Who Have To Apply The Formula”(Hartiwiningsih,2008:67).

Keberhasilan misi hukum untuk menekan penggunaan kawasan hutan yang tidak prosedural tidak hanya ditentukan oleh sempurnanya formulasi hukum yang dirumuskan dalam hukum positif.Melainkan lebih dari itu keberhasilannya sangat tergantung kepada aparat yang melaksanakannya. Konsekuensi logisnya, aparat penegak hukum harus memiliki kemampuan lebih dan profesi di dalam menangani penggunaan kawasan yang melanggar aturan dan keberanian moral aparat penegak hukum dituntut sekaligus diuji untuk melakukan penemuan hukum (Rechtvinding), sehingga tidak ada alasan klasik yang bersembunyi dibalik asas legalitas sempit bahwa aturan perundang-undangan tidak lengkap atau belum ada perundang-undangan yang mengaturnya. Aparat penegak hukum harus memiliki kemampuan lebih dan keberanian di dalam melakukan penertiban pengusaha sawit yang tidak memiliki ijin pelepasan kawasan hutan, karena apabila dilakukan penertiban atau melalui operasi pasti ada, kondisi tersebut sangat memprihatinkan.

Di Indonesia yang merupakan struktur dari sistem hukum, yaitu: Advokat, Polisi, Jaksa, Hakim dan para penegak hukum lainnya. Para penegak hukum lainnya adalah mereka ditunjuk undang-undang atau peraturan-peraturan seperti yang diatur dalam Undang-Undang Nomor 41 Tahun 1999 Tentang Kehutanan yaitu selain aparat penegak hukum pada umumnya juga dapat dilakukan oleh Pejabat Pegawai Negeri Sipil tertentu di lingkungan kehutanan yang diberi kewenangan sebagai Penyidik.

\section{Faktor Sarana dan Fasilitas.}

Secara sederhana fasilitas dapat dirumuskan sebagai sarana untuk mencapai tujuan, tanpa adanaya sarana atau fasilitas tertentu, maka tidak mungkin penegakan hukum akan berlangsung dengan lancar. Sarana atau fasilitas tersebut antara lain, mencakup tenaga manusia yang berpendidikan dan terampil, organisasi yang baik, peralatan yang memadai, keuangan yang cukup, dan 
seterusnya. Kalau hal-hal itu tidak terpenuhi, maka mustahil penegakan hukum akan mencapai tujuannya.

Faktor ini dapat dikatakan sebagai tulang punggung penegakan hukum terhadap pengelola perkebunan sawit yang tidak tertib.Sebab eksistensinya merupakan penopang keberhasilan untuk menemukan suatu kebenaran materiel. Oleh karena jalinan kerjasama yang harmonis antara lembaga penegak hukum dengan beberapa pakar dan dana oprasional yang memadai adalah merupakan faktor pendukung guna melatih masyarakat untuk disiplin mematuhi aturan yang berlaku, hal itu dilakukan sebagai upaya mempersempit ruang gerak pengelola perkebunan sawit yang tidak tertib.

Dalam hal sarana dan fasilitas untuk penerapan Undang-Undang Nomor 41 Tahun 1999 oleh penegak hukum sebenarnya secara umum telah terpenuhi.Ini bisa dilihat dari isi undang-undang tersebut yang cukup jelas dan kewenangan yang diberikan kepada penegak hukum sebagai sarana untuk menertibkan.

\section{Faktor Masyarakat}

Penegakan hukum hendaknya tidak dilihat sebagai suatu yang berdiri sendiri, melainkan selalu berada diantar berbagai faktor (Interchange).Hukum senantiasa dibatasi oleh situasi atau lingkungan di mana ia berada, sehingga tidak heran kalau terjadi ketidak cocokan antara apa yang seharusnya (Dan Sollen) dengan apa yang senyatanya (Das Sein). Dengan perkataan lain, muncul diskrepansi antara law in the books dan law in action.

Berbicara mengenai warga masyarakat maka hal ini sedikit banyak mengyakut masalah derajad kapatuhan.Secara sempit dapat dikatakan bahwa derajad kepatuhan masyarakat terhadap hukum salah satu indikator berfungsinya hukum yang bersangkutan.Artinya apabila derajad kepatuhan terhadap Undang-Undang Nomor 41 Tahun 1999 tinggi, maka peraturan-peraturan tersebut memang berfungsi.Tetapi masalahnya ketaatan terhadap hukum kehutanan khususnya penggunaan kawasan hutan saat ini sangat rendah, terbukti semakin tingginya 
tingkat kerusakan terhadap kawasan hutan di Riau baik secara kaualitas maupun kuantitas.

Rendahnya tingkat kepatuhan hukum masyarakat terhadap peraturan perundang-undangan di bidang kehutanan saat ini tidak terlepas dari kesalahan masa lalu, dimana pada masa pemerintahan orde baru, pembangunan ekonomi nasional yang berorientasi untuk mengejar pertumbuhan ekonomi (Economic Growth Development), menyebabkan pemerintah secara sadar mengeksploitasi sumber daya hutan dan kekayaan alam lainnya, sebagai sumber pendapatan dan devisa negara (State Revenue) untuk membiayai pembangunan nasional

\section{Faktor Budaya}

Dalam bahasa awam, budaya itu adalah pandangan filosofis mengenai apa yang dipercayai dan diyakini sebagai sesuatu yang baik dan harus dijaga. Jika kita selama ini mendapati type kebudayaan yang penuh dengan kepura-puraan, kebudayaan yang tidak menghormati hukum, kebudayaan yang selalu ingin untung dan berorientasi kepada materi maka harus kita akui kebudayaan kita tidak baik.

Fungsi hukum tidak cukup hanya sebagai control sosial. Fungsi hukum yang diharapkan dewasa ini adalah melakukan usaha untuk menggerakan rakyat agar bertingkah laku sesuai dengan cara-cara baru untuk mencapai suatu tujuan yang dicita-citakan karena itu perlu ada kesadaarn hukum dari masyarakat.Kesadaran hukum masyarakat itu terkait erat dengan masalah budaya hukum.Berbicara mengenai budaya hukum adalah berbicara mengenai bagaimana sikap-sikap, pandanganpandangan serta nilai-nilai yang dimiliki oleh masyarakat.

Menurut Soerjono Soekanto bahwa kebudayaan (sistem) hukum pada dasarnya mencakup nilai-nilai yang mendasari hukum yang berlaku, nilai yang merupakan konsepsi-konsepsi abstrak mengenai apa yang dianggap baik (sehingga dianut) dan apa yang dianggab buruk (sehingga dihindari). Lebih lanjut

dijelaskan bahwa nilai-nilai tersebut, lazimnya merupakan pasangan nilai-nilai 
yang mencerminkan dua keadaan ekstrim yang harus diserasikan (Soerjono Soekanto, 2010:60).

Budaya hukum seseorang akan diinternalisasi melalui perilaku individu yang dipengaruhi oleh kondisi lingkungan seperti jauh tidaknya dari jangkauan kontrol sosial baik formal maupun informal termasuk adanya godaan dan provokasi dari pelaku tindak pidana yang tidak diganjar dengan hukuman atas perbuatan yang dilakukannya. Hal ini seperti yang dikemukakan oleh Per-Olof H. Wikström, bahwa: "Communities Vary In Environmental Conditions Conducive To Crime, Including Their Levels Of Formal And Informal Social Controls And, Partly Related To That, Their Levels Of Temptations And Provocations."(Per-Olof H. Wikström dikutip dari Adam Benforado, 2010:11).(Bermacam kejahatan dalam lingkungan masyarakat, kontrol sosial formal dan informal dapat menciptakan suasana kondusif, terkait dengan, tingkat godaan dan provokasi mereka).

Selain itu akibat kesalahan masa lalu, dimana pembangunan ekonomi nasional yang berorientasi untuk mengejar pertumbuhan ekonomi (Economic Growth Development), telah menyebabkan muncul kelompok masyarakat lokal, terutama masyarakat yang secara turuntemurun hidup dan tinggal di dan sekitar hutan, sebagai korban-korban pembangunan (Victims Of Development), yang tergusur dan terabaikan serta terbekukannya akses dan hak-hak mereka atas sumber daya hutan, berubah menjadi masyarakat yang anarkis. Akibatnya, terjadi konflikkonflik yang berkepanjangan atas pengelolaan dan pemanfaatan sumber daya hutan antara masyarakat lokal dengan pemerintah maupun pemegang konsesikonsesi kehutanan.

\section{Simpulan.}

Peraturan Perundang-undangan di sektor Kehutanan terkait masalah penggunaan kawasan hutan tidak mengakomodasi kegiatan yang lebih baik dan terbuka sedang dalam praktik penyelenggaraan Pemerintah khususnya disektor kehutanan masih dirasa adanya tuntutan rasa ketidak keadilan di masyarakat bahwa kebijakan kehutanan belum berpihak kepada rakyat ini dapat di lihat di 
lapangan pemerintah malah mendahului investor untuk melakukan kegiatan usaha perkebunan maupun sebagainya ketimbang masyarakat itu sendiri.

Dipengaruhi oleh substansi yaitu faktor hukumnya sendiri (UndangUndang) diantarnya pembatasan kewenangan PPNS Kehutanan, belum adanya sanksi minimal dan maksimal; struktur yaitu faktor penegak hukum, diantarnya masih kurangnya kuantitas dan kualitas SDM dan kurangnya dukungan dari intansi penegak hukum lainya, dan kultur yaitu faktor budaya, diantaranya adalah adanya perubahan perilaku masyarakat disekitar KHDTK menjadi lebih konsumtif.

\section{E. Saran.}

Perlu adanya sinergitas kegiatan kehutanan di kawasan hutan dengan tujuan untuk menghindari tumpang tindih kegiatan yang menyebabkan terhentinya iklim invertasi di dua sektor tersebut, agar supaya kesejahteraan masyarakat dan kelestarian hutan terwujud.Tumpang tindih pemegang izin pemanfaatan hutan dan pengelolaan hutan dengan kegiatan dilakukan dengan pendekatan musyawarah dan membangun kesepahaman.Apabila musyawarah tidak tercapai maka penyelesaian secara hukum sebagai upaya penyelesaian akhir.

Peran Pemerintah Daerah dalam menetapkan kebijakan hendaknya mengacu pada peraturan perundang-undangan yang berlaku serta memperhatikan pada kebutuhan riil di masyarakat.Perlu segera diterbitkan Peraturan Pemerintah tentang penggunaan kawasan hutan untuk kegiatan di luar pembangunan kehutanan, sebagai pedoman penentu kebijakan dalam pengelolaan hutan dan penggunaan di kawasan hutan.Perlu segera dilakukan harmonisasi hukum yang mengatur sumberdaya alam agar panggilan jiwa Pasal 33 ayat (3) Undang-Undang Dasar 1945 dapat terwujud. 7. Ketentuan Pasal 19 Undang-undang No. 41 tahun 1999 dapat digunakan sebagai koridor perubahan peruntukan dan fungsi kawasan hutan. Untuk itu, segera diterbitkan Peraturan Pemerintah tentang Tata Cara Perubahan Peruntukan dan Fungsi Kawasan Hutan. 


\section{F. Daftar Pustaka}

1. Buku

Esmi Warrasih.2005.Pranata Hukum Sebuah Telaah Sosiologis.Semarang; Suryanadaru Utama.

Hartiwiningsih.2008.Hukum Lingkungan dalam Perspektif Kebijakan Hukum Pidana.Surakarta;Cetakan 1.UNS Press.

H.S. Salim. 2005.Dasar-Dasar Hukum Kehutanan.Jakarta. Sinar Grafika.

Mukti Fajar ND dan Yulianto Achmad.2010.Duelisme Penelitian Hukum nermatif \& Empiris. Yogyakarta;Pustaka Pelajar.

Nurdjana. Teguh Prasetyo.2005. Sukardi, Korupsi dan Illegal Logging Dalam Sistem Desentralisasi.Yogya;Pustaka Pelajar.

Panji Suminar.2004. "Pengembangan Model Solusi Konflik Hutan Konservasi Di Tiga Komunitas Bengkulu”. Laporan Penelitian RUKK III.3, Lembaga Penelitian Universitas Bengkulu.

Peter Mahmud Marzuki.2005.Penelitian Hukum.Jakrta; Kencana.

Per-Olof H. Wikström dikutip dari Adam Benforado.2010. "The Geography of Criminal Law”, article in Cardozo Law Review January, Yeshiva University.

Satjipto Rahardjo.1986.Masalah Penegakan Hukum.Bandung;Sinar Baru.

_. 2010.Sosiologi Hukum, Perkembangan Metode dan Pilihan Masalah,Bandung; Genta Publishing.

Soerjono Soekanto. 2009. Faktor-Faktor Yang Mempengaruhi Penegakan Hukum,Jakarta;Raja Grafindo Persada.

Siswarno Sunarso. 2005.Hukum Pidana Lingkungan Hidup dan Strategi Penyelesaian Sengketa.Jakarta;Rineka Cipta.

Winarno Budyatmojo. 2009.Kodifikasi Hukum Pidana. Surakarta.UNS Press ,2008,Tindak Pidana Illegal Logging. Surakarta;UNS Press.

\section{Undang-undang}

Penjelasan Atas Undang-Undang Republik Indonesia Nomor 41 Tahun 1999 Tentang Kehutanan 
Undang-undang pokok Agraria No 05 Tahun 1990

Peraturan Pemerintah No 24 Tahun 2010

\section{Jurnal}

I Gusti Ayu Ketut Rachmi Handayani.2016.Faktor-faktor yang berpengaruh terhadap penegakan hukum kehutanan di Indonesia.Jurnal EKOSAINS I Vol. IV | No. 2 | 11 Desember 2016

Epi Syahadat,2012Permasalahan Penataan Ruang Kawasan Hutan Dalam Rangka Revisi Rencana Tata Ruang Wilayah Provinsi (Problems On Forest And Land Use System For Revision Ofprovincial Land Use System),Jurnal Analisis Kebijakan Kehutanan Vol. 9 No. 2, Agustus 2015: 131 - 143

A. M. Yunus Wahid,2015Penegakan Hukum Lingkungan di Sektor Kehutanan (Studi Kawasan Hutan Lindung di Kabupaten Sinjai, Sulawesi Selatan) The Environmental Law Enforcemnent in Forestry Sector (Study on the Protected Forest in Sinjai Region, South Sulawesi),Jurnal Hasanuddin Law Review Vol. 1 No. 1, April 201563 